\title{
ABBREVIATIONS AND SHORT TITLES
}

\section{General abbreviations}

Ælfric, $C H: F S$

Ælfric, $C H: S S$

Ælfric, $L S$

Ælfric, Supplementary

Homilies

ANS

$A S C$

ASE

$\mathrm{BL}$

$B N J$

$\mathrm{CCCM}$

CCSL
Ælfric of Eynsham, Catholic Homilies: The First Series, ed. P. Clemoes, EETS s.s. 17 (Oxford, 1997)

Ælfric of Eynsham, Catholic Homilies: The

Second Series, ed. M. Godden, EETS s.s. 5

(Oxford, 1979)

Ælfric of Eynsham, Lives of Saints, ed. W.W.

Skeat, 4 pts, EETS o.s. 76, 82, 94, 114 (Oxford, 1881-1900; repr. as 2 vols., Oxford, 1966)

Homilies of Elfric: A Supplementary Collection, ed. J.C. Pope,

2 pts, EETS o.s. 259-60 (London, 1967-8)

Anglo-Norman Studies

Anglo-Saxon Chronicle

Anglo-Saxon England

London, British Library

British Numismatic Journal

Corpus Christianorum Continuatio Mediaevalis

Corpus Christianorum Series Latina 


\begin{tabular}{|c|c|}
\hline$D A$ & Deutsches Archiv für Erforschung des Mittelalters \\
\hline EEMF & Early English Manuscripts in Facsimile \\
\hline EETS & Early English Text Society \\
\hline Whitelock, EHD & $\begin{array}{l}\text { English Historical Documents c. 500-1042, ed. } \\
\text { D. Whitelock, } 2^{\text {nd }} \text { edn (London, 1979) }\end{array}$ \\
\hline$E H R$ & English Historical Review \\
\hline$E M E$ & Early Medieval Europe \\
\hline FMSt & Frühmittelalterliche Studien \\
\hline HBS & Henry Bradshaw Society \\
\hline HSJ & Haskins Society Journal \\
\hline$H Z$ & Historische Zeitschrift \\
\hline$J E G P$ & Journal of English and Germanic Philology \\
\hline MGH: & Monumenta Germaniae Historica: \\
\hline Cap. n.s. & Capitularia regum Francorum: nova series \\
\hline Conc. & Concilia \\
\hline Epp. & Epistolae \\
\hline SS & Scriptores \\
\hline SS rer. Germ. & $\begin{array}{l}\text { Scriptores rerum Germanicarum in usum } \\
\text { scholarum }\end{array}$ \\
\hline SS rer. Germ. n.s. & Scriptores rerum Germanicarum: nova series \\
\hline NC & Numismatic Chronicle \\
\hline$O D N B$ & $\begin{array}{l}\text { Oxford Dictionary of National Biography, ed. } \\
\text { H.C.G. Matthew and B. Harrison, } 60 \text { vols. } \\
\text { (Oxford, 2004) }\end{array}$ \\
\hline PL & $\begin{array}{l}\text { Patrologia Cursus Completus. Series (Latina) } \\
\text { Prima, ed. J.-P. Migne, } 221 \text { vols. (Paris, 1844-64) }\end{array}$ \\
\hline$P \& P$ & Past and Present \\
\hline SCH & Studies in Church History \\
\hline Scriftboc & $\begin{array}{l}\text { Scriftboc, ed. A. Frantzen, 'The Anglo-Saxon } \\
\text { Penitentials: A Cultural Database' (http://www. } \\
\text { anglo-saxon.net/penance/, accessed } 13 \text { January } \\
\text { 2016) }\end{array}$ \\
\hline TRHS & Transactions of the Royal Historical Society \\
\hline
\end{tabular}




\section{Abbreviations for Anglo-Saxon charters}

Anglo-Saxon charters are cited by their 'S number' from P.H. Sawyer, Anglo-Saxon Charters: An Annotated List and Bibliography, rev. S.E. Kelly and R. Rushforth (http://www.esawyer.org.uk/) with an edition given in parentheses. For these purposes the following abbreviations are used:

BCS

W. de G. Birch, ed., Cartularium Saxonicum: A Collection of Charters Relating to Anglo-Saxon History, 3 vols. (London, 1885-93)

KCD J.M. Kemble, ed., Codex Diplomaticus Aevi Saxonici, 6 vols. (London, 1839-48)

Abing

S.E. Kelly, ed., Charters of Abingdon Abbey, 2 pts, Anglo-Saxon Charters 7-8 (Oxford, 2000-1)

Bath S.E. Kelly, ed., Charters of Bath and Wells, Anglo-Saxon Charters 13 (Oxford, 2007)

Burt P.H. Sawyer, ed., Charters of Burton Abbey, Anglo-Saxon Charters 2 (Oxford, 1979)

CantCC

N. Brooks and S.E. Kelly, ed., Charters of Christ Church, Canterbury, 2 pts, Anglo-Saxon

Charters 17-18 (Oxford, 2013)

CantStA

S.E. Kelly, ed., Charters of St Augustine's Abbey,

Canterbury, and Minster-in-Thanet, Anglo-

Saxon Charters 4 (Oxford, 1995)

Glast

S.E. Kelly, ed., Charters of Glastonbury Abbey, Anglo-Saxon Charters 15 (Oxford, 2012)

LondStP

S.E. Kelly, ed., Charters of St Paul's, London, Anglo-Saxon Charters 10 (Oxford, 2004)

Malm

S.E. Kelly, ed., Charters of Malmesbury Abbey, Anglo-Saxon Charters 11 (Oxford, 2005)

Pet S.E. Kelly, ed., Charters of Peterborough Abbey, Anglo-Saxon Charters 14 (Oxford, 2009) 
Roch

Sel

Shaft

Sherb

StAlb

Wells

WinchNM

A. Campbell, ed., Charters of Rochester, AngloSaxon Charters 1 (London, 1973)

S.E. Kelly, ed., Charters of Selsey, Anglo-Saxon Charters 6 (Oxford, 1996)

S.E. Kelly, ed., Charters of Shaftesbury Abbey, Anglo-Saxon Charters 5 (Oxford, 1995) M.A. O'Donovan, ed., Charters of Sherborne, Anglo-Saxon Charters 3 (Oxford, 1988) J. Crick, ed., Charters of St Albans, Anglo-Saxon Charters 12 (Oxford, 2007) S.E. Kelly, ed., Charters of Bath and Wells, Anglo-Saxon Charters 13 (Oxford, 2007) S. Miller, ed., Charters of the New Minster, Winchester, Anglo-Saxon Charters 9 (Oxford, 2001) 


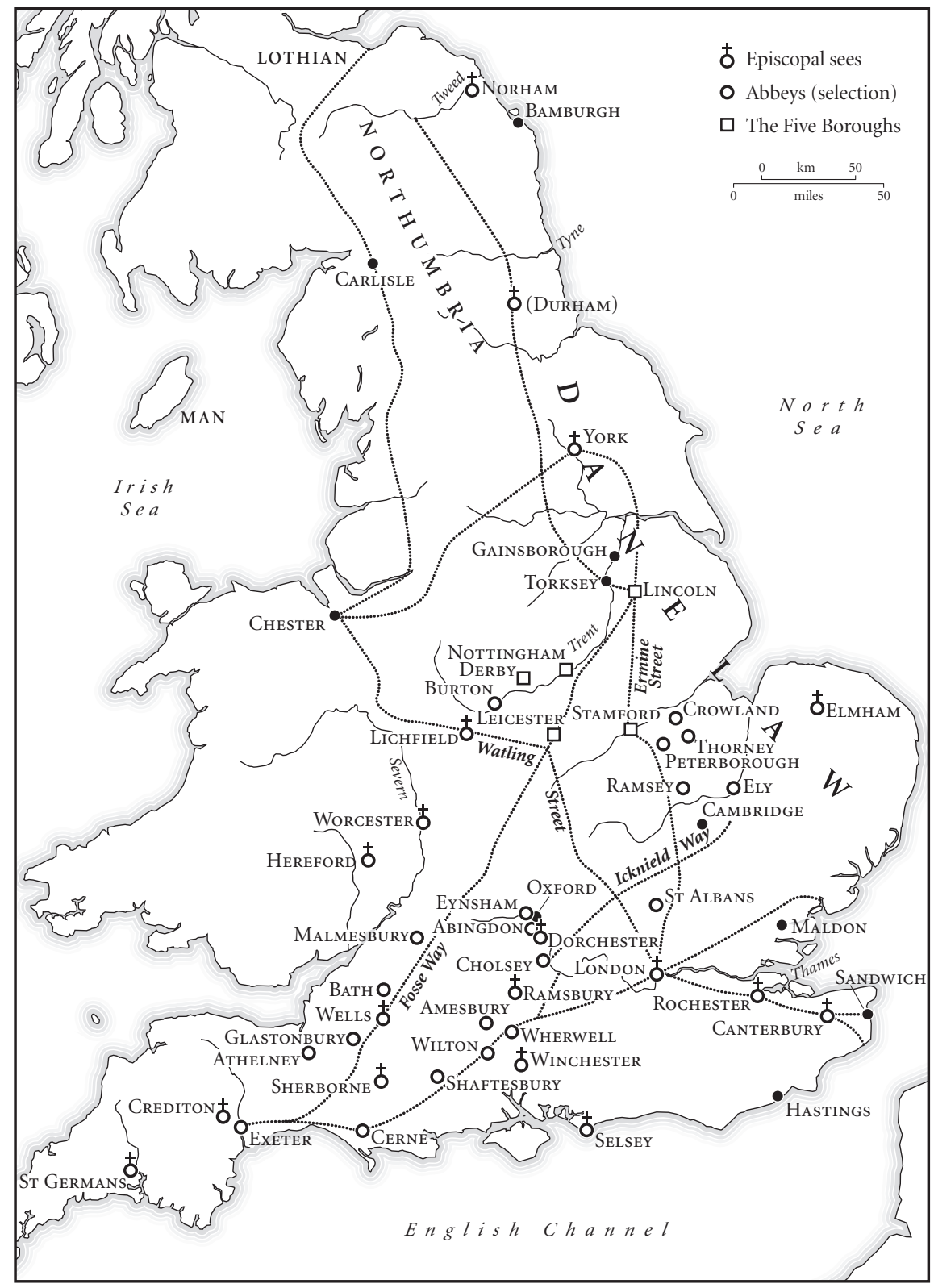

Map 1 England in the reign of Æthelred II. 


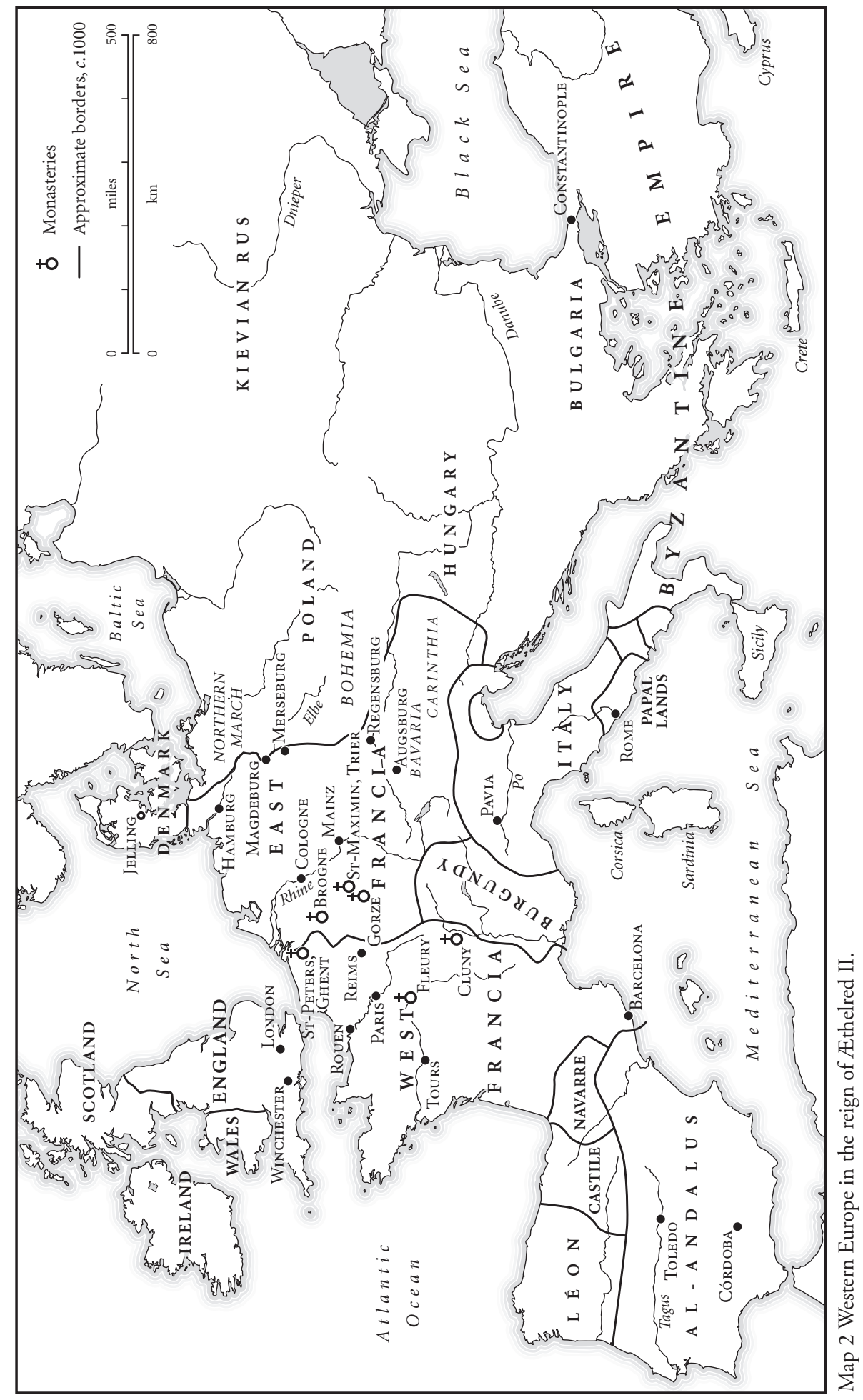




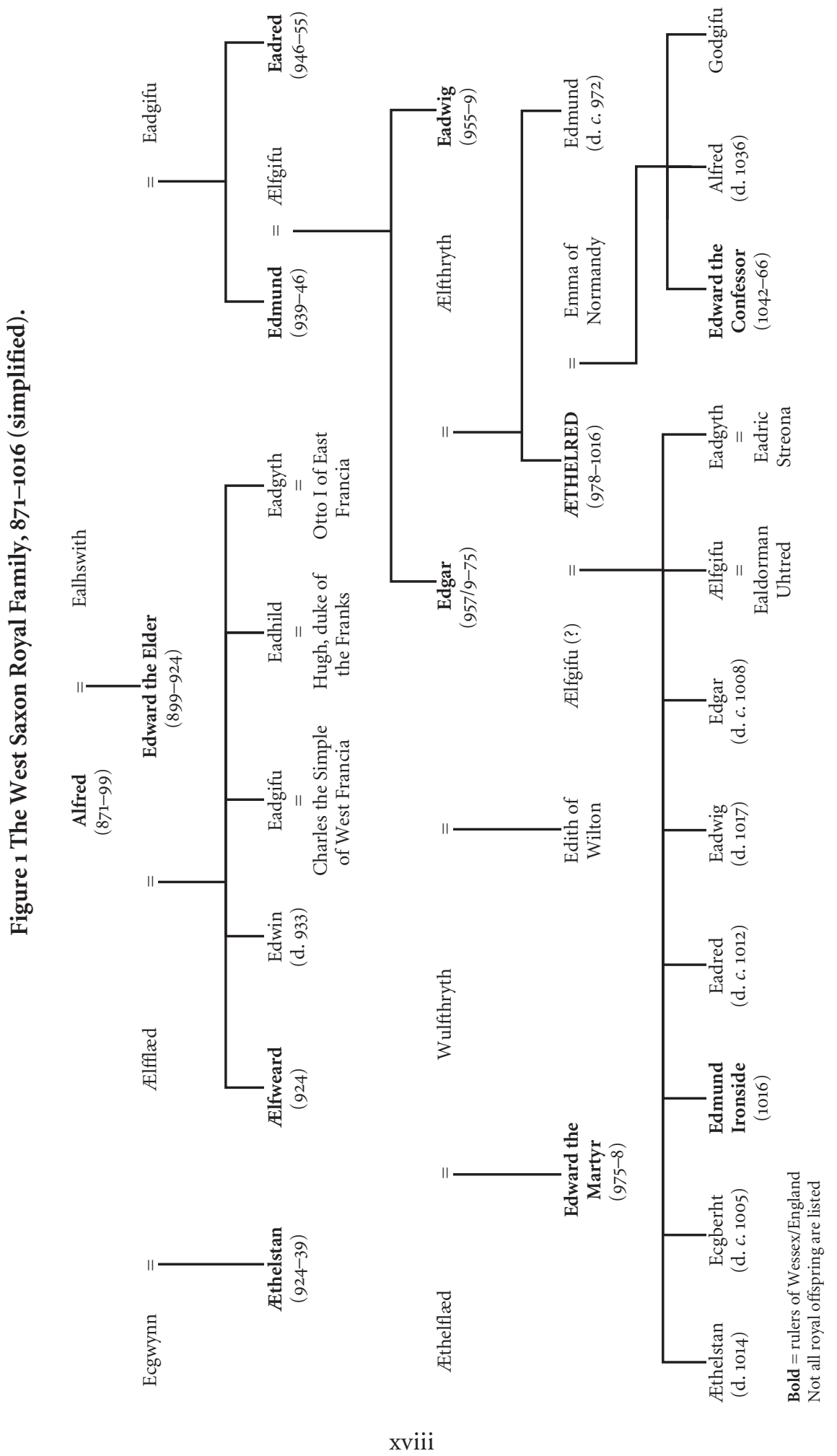




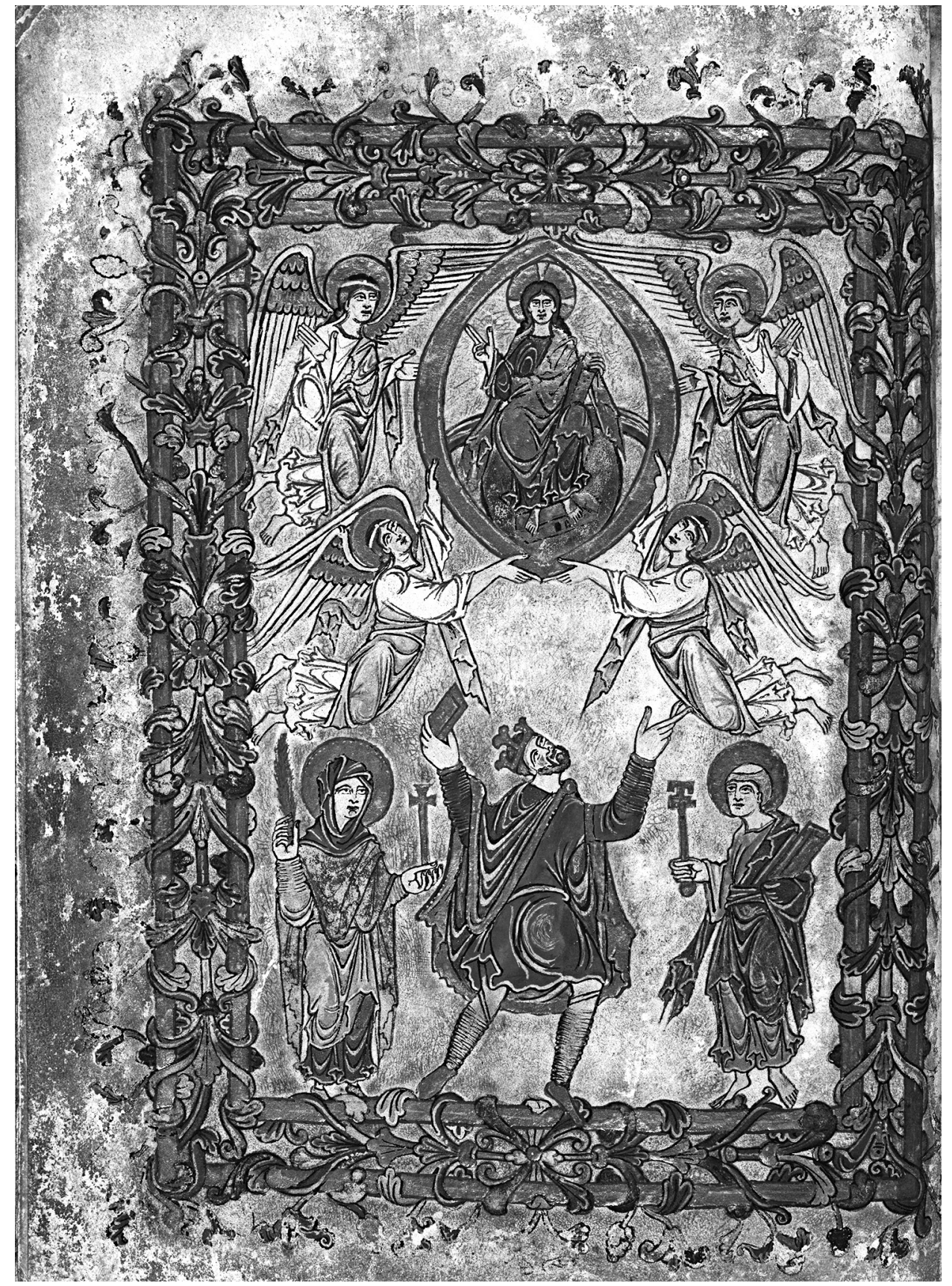

1 Frontispiece of the New Minster Refoundation Charter: King Edgar, stationed between the Virgin Mary and St Peter, presents the charter (in his left hand) to Christ. 


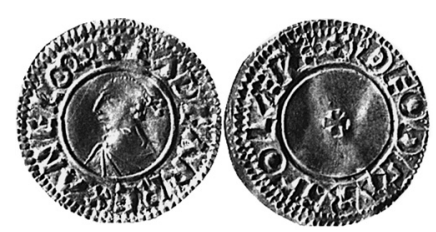

a

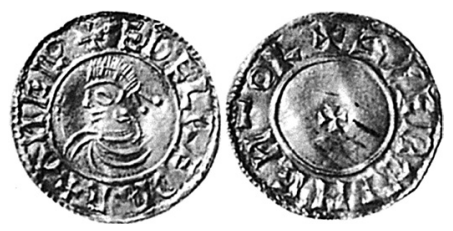

C
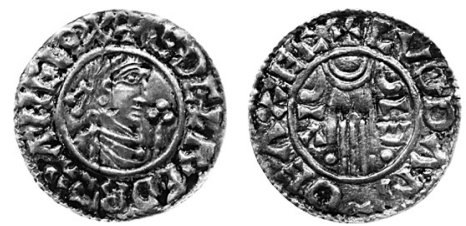

e

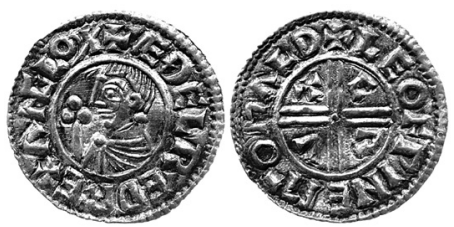

g
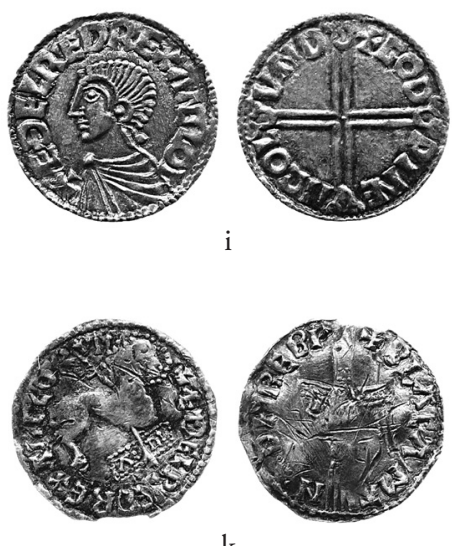

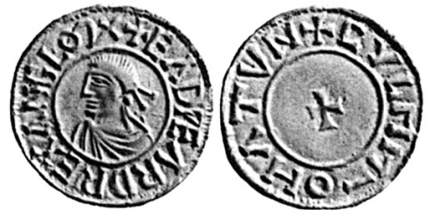

b

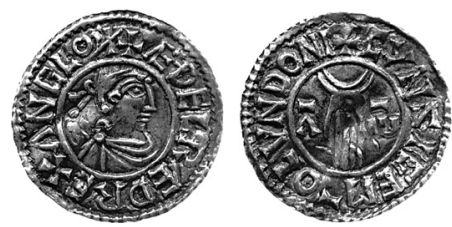

$\mathrm{d}$

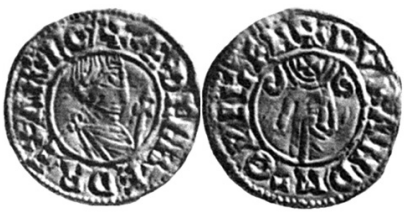

f

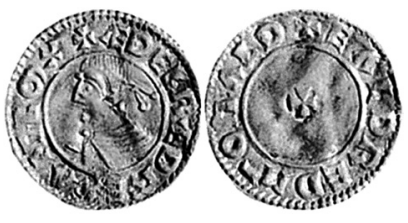

$\mathrm{h}$
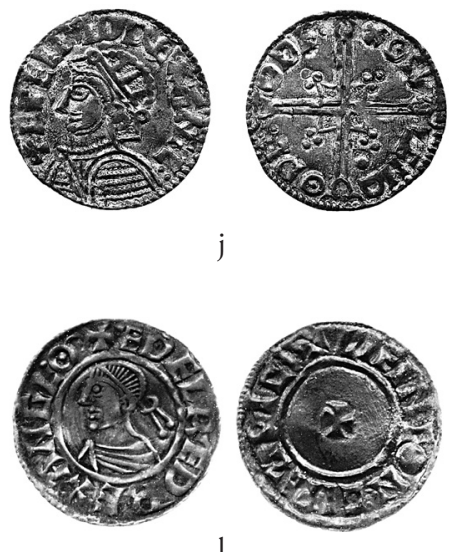

1

2 Post-reform coinage of Edgar, Edward the Martyr and Æthelred: a) Edgar, Reform Small Cross; b) Edward, Small Cross; c) Æthelred, First Small Cross; d) Æthelred, First Hand; e) Æthelred, Second Hand; f) Æthelred, Benediction Hand; g) Æthelred, Crux; h) Æthelred, Intermediate Small Cross; i) Æthelred, Long Cross; j) Æthelred, Helmet; k) Æthelred, Agnus Dei; 1) Æthelred, Last Small Cross. 

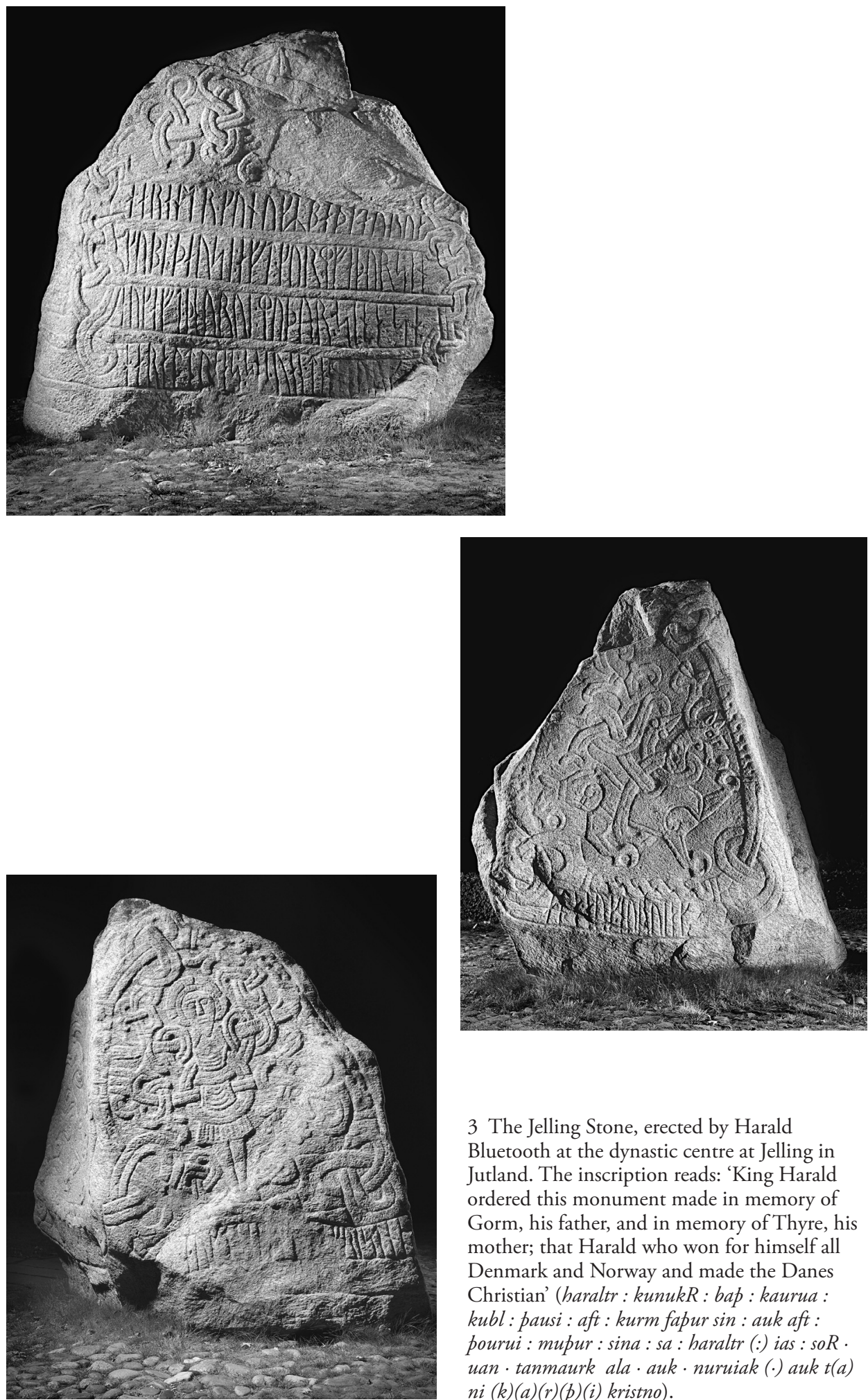

3 The Jelling Stone, erected by Harald Bluetooth at the dynastic centre at Jelling in Jutland. The inscription reads: 'King Harald ordered this monument made in memory of Gorm, his father, and in memory of Thyre, his mother; that Harald who won for himself all Denmark and Norway and made the Danes Christian' (haraltr : kunukR : bap : kaurua : kubl: pausi : aft : kurm fapur sin : auk aft : pourui : mupur: sina : sa : haraltr (:) ias : soR . uan - tanmaurk ala $\cdot$ auk $\cdot$ nuruiak (.) auk $t($ a) $n i(k)(a)(r)(p)(i) k r i s t n o)$. 

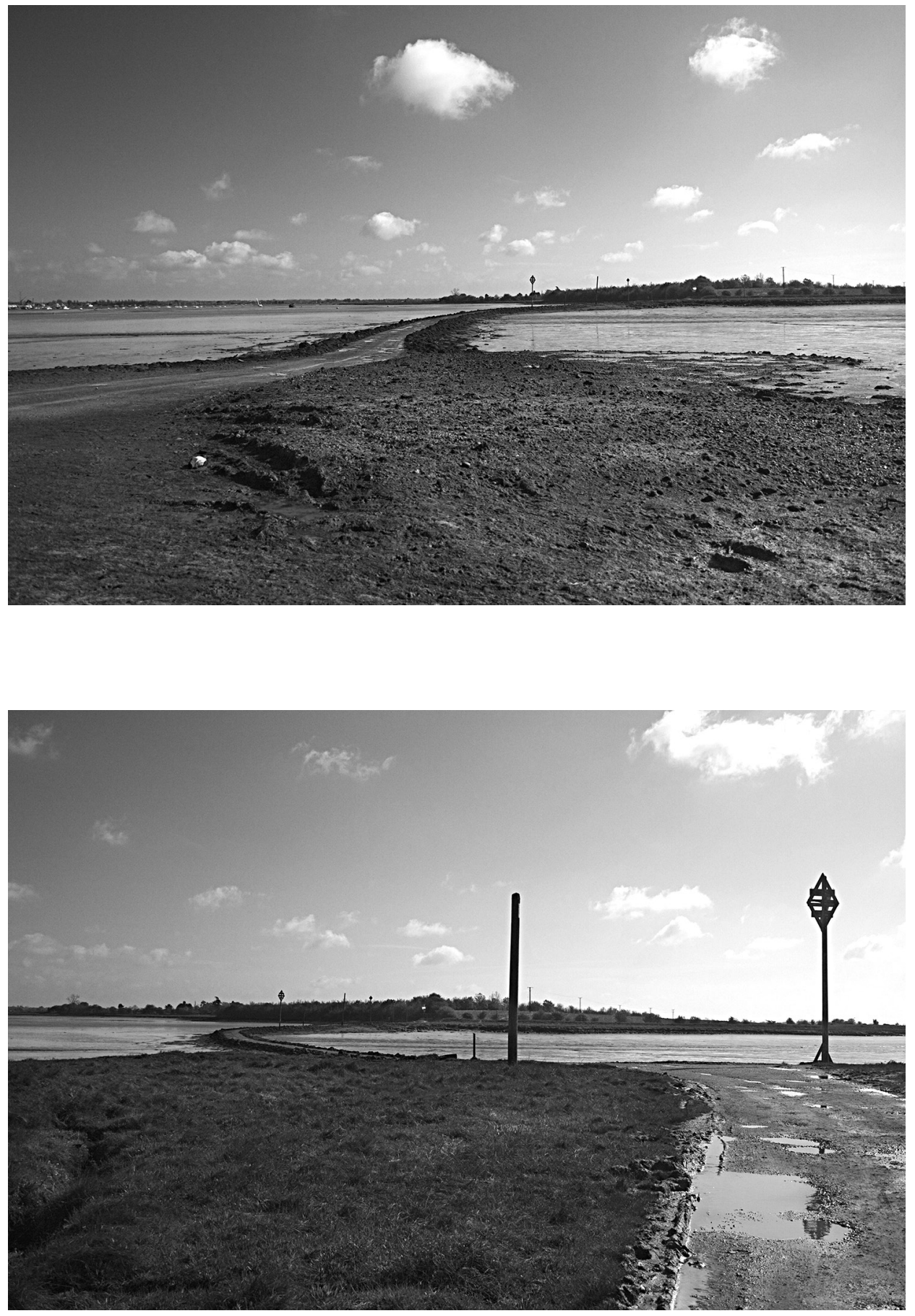

4 The tidal causeway between Maldon and Northey Island, Essex, where the Battle of Maldon was reputedly fought. 


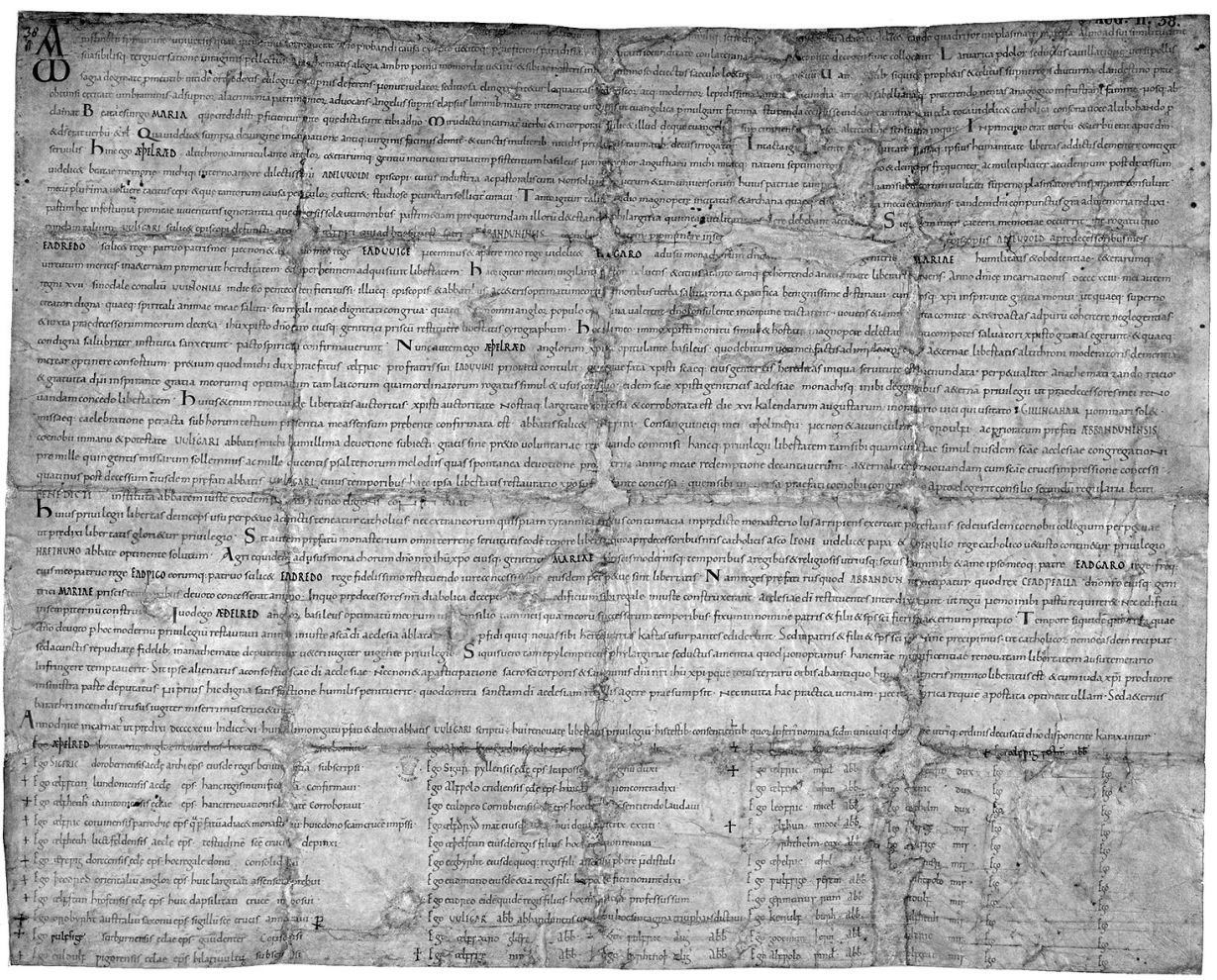

5 Restitution of liberty to Abingdon, enacted at Winchester at Pentecost (4 June) 993 and completed at Gilligham (? Dorset) on 17 July. 


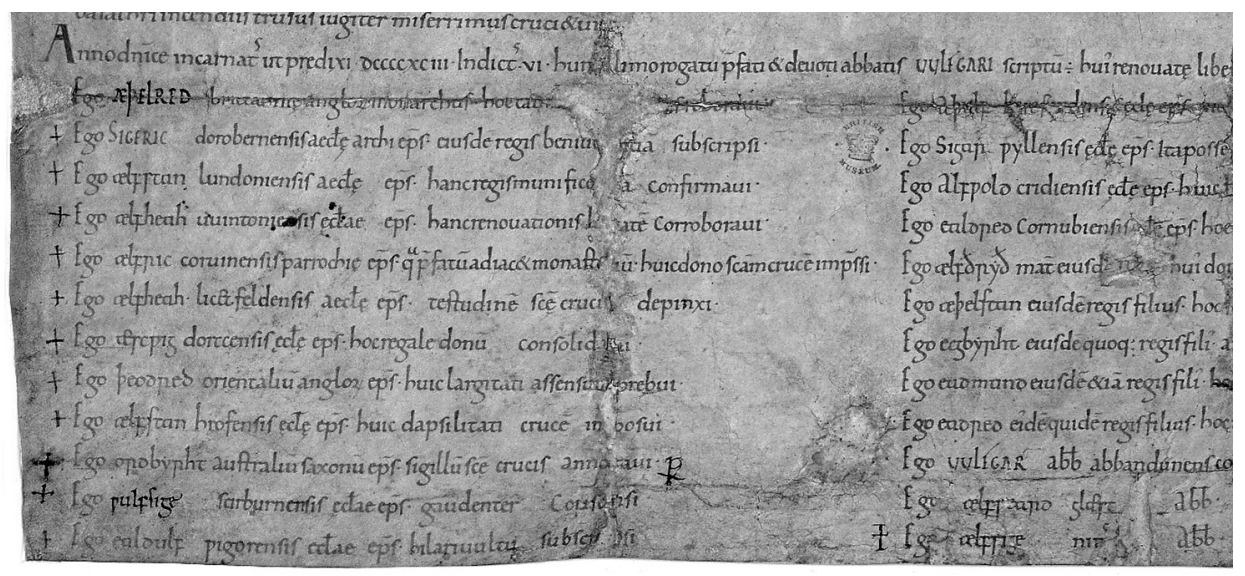

6 Witness-list to the restitution of liberty to Abingdon in 993: note the different shape and aspect of many of the crosses, suggesting that these were added by the attestors themselves, probably at the Gillingham gathering (17 July).

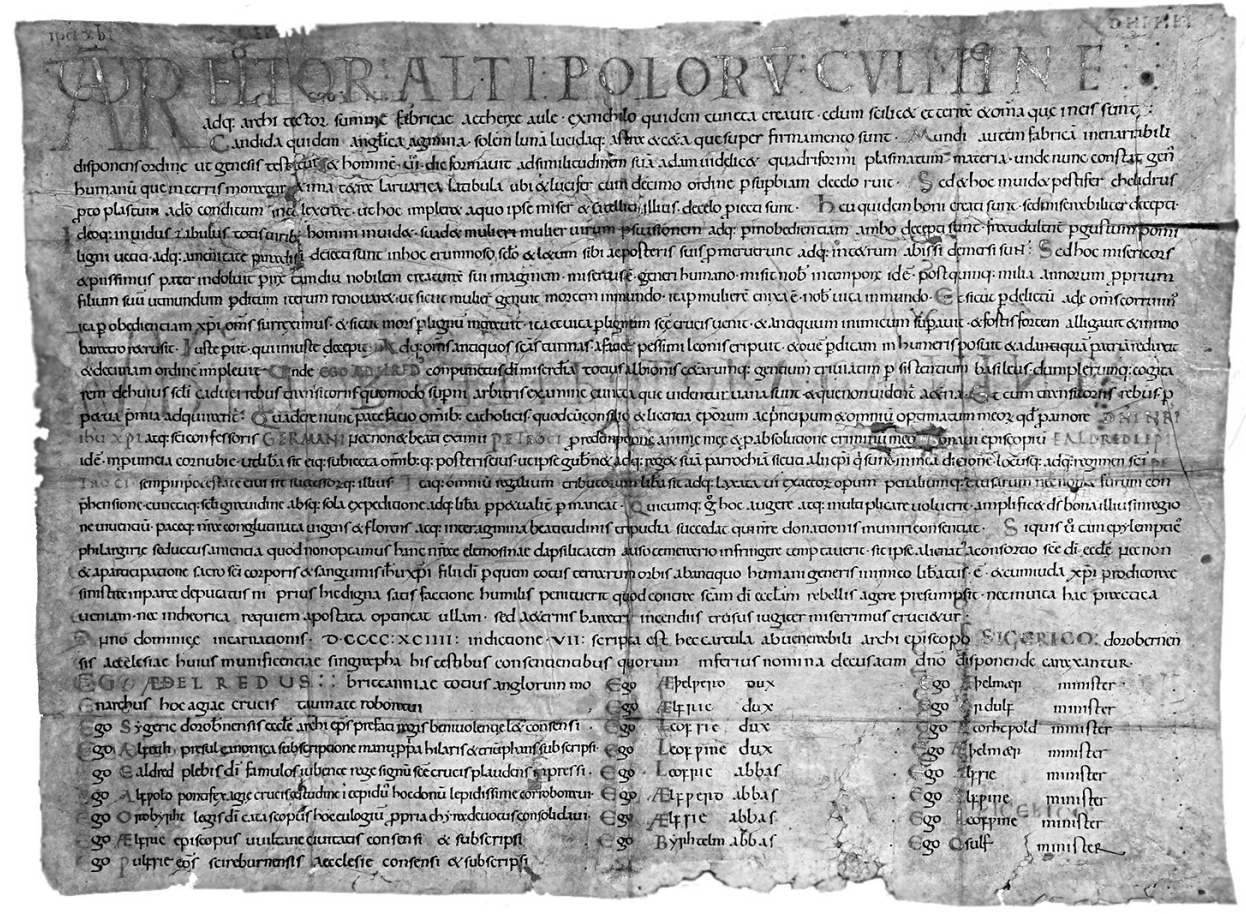

7 Confirmation of liberty to the bishopric of Cornwall in 994, written partly in gold script, perhaps drafted by Archbishop Sigeric of Canterbury. 


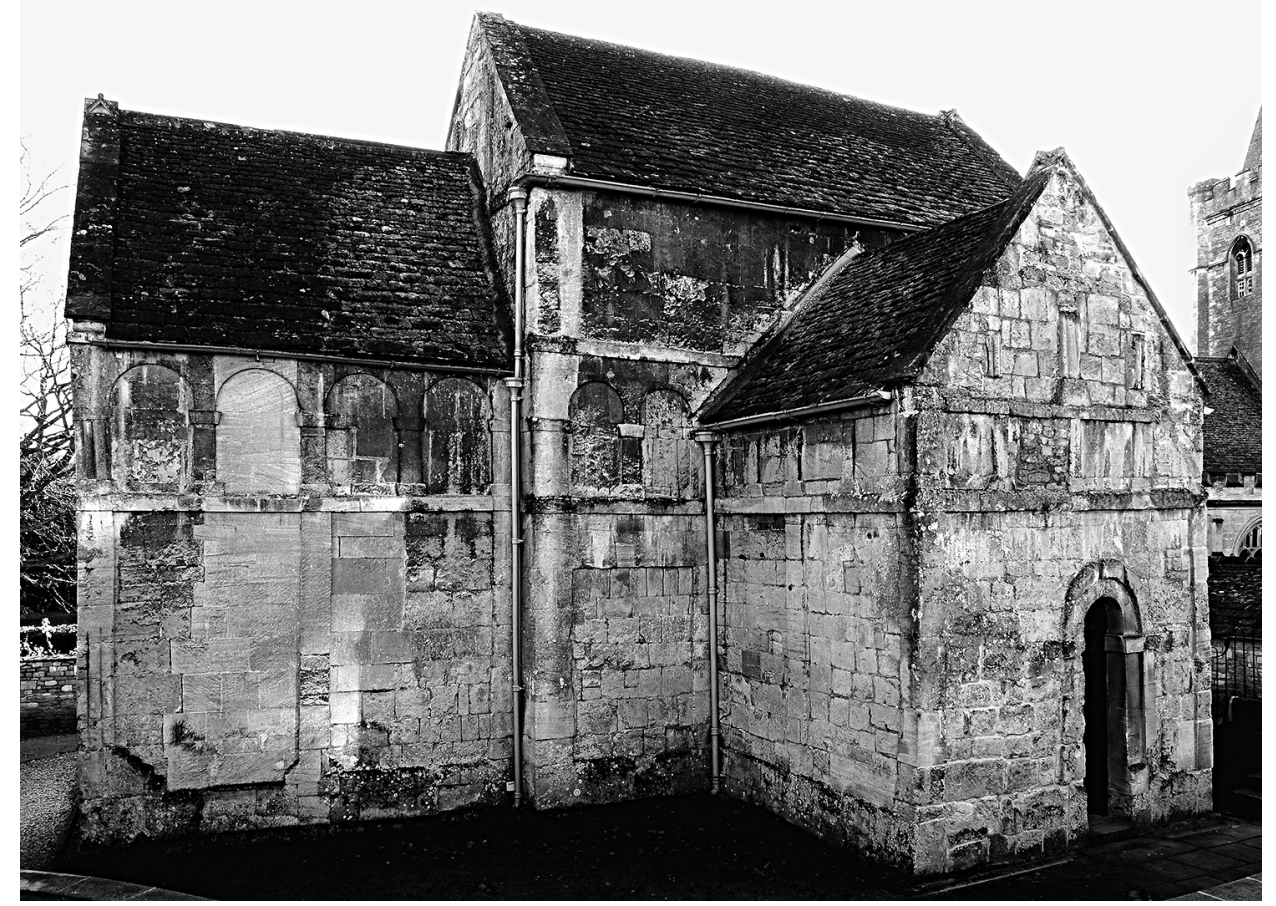

8 The unfinished chapel at Bradford-on-Avon, maybe constructed to house the relics of Edward's halfbrother, Edward the Martyr.

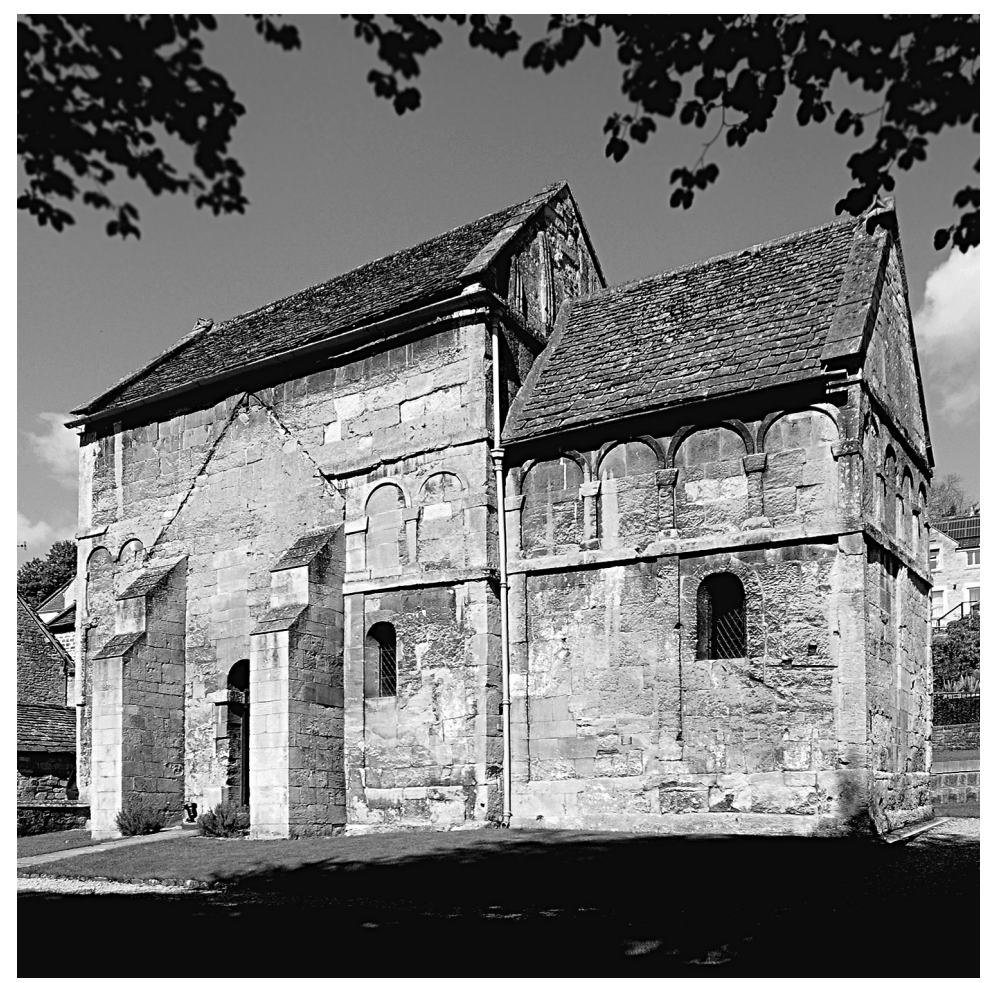




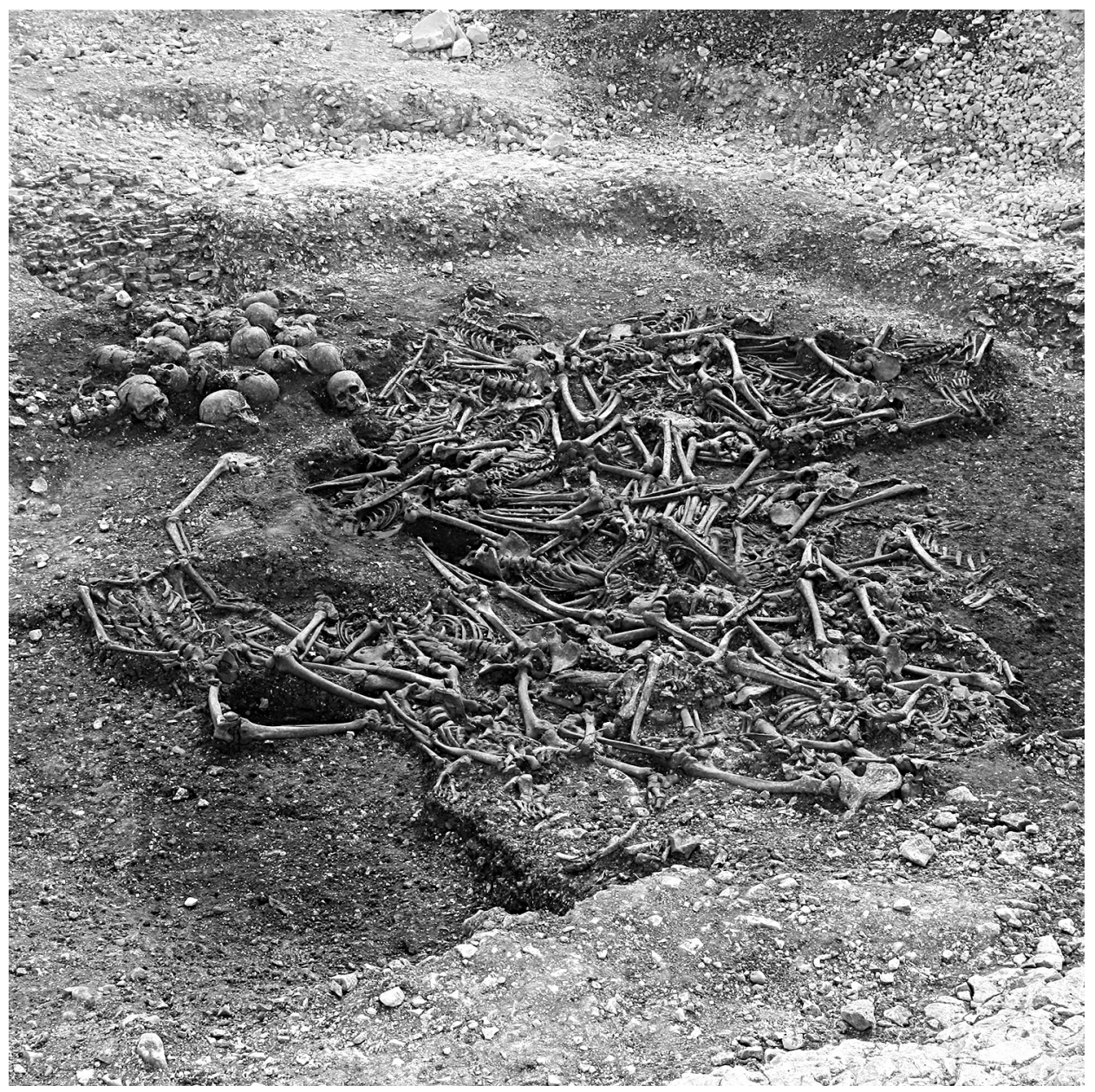

9 Execution burial at Ridgeway Hill, Dorset. The victims were all male and probably of Scandinavian origin. It is likely that they met their demise during Æthelred's reign, possibly as a consequence of the Massacre of St Brice's Day (1002). 


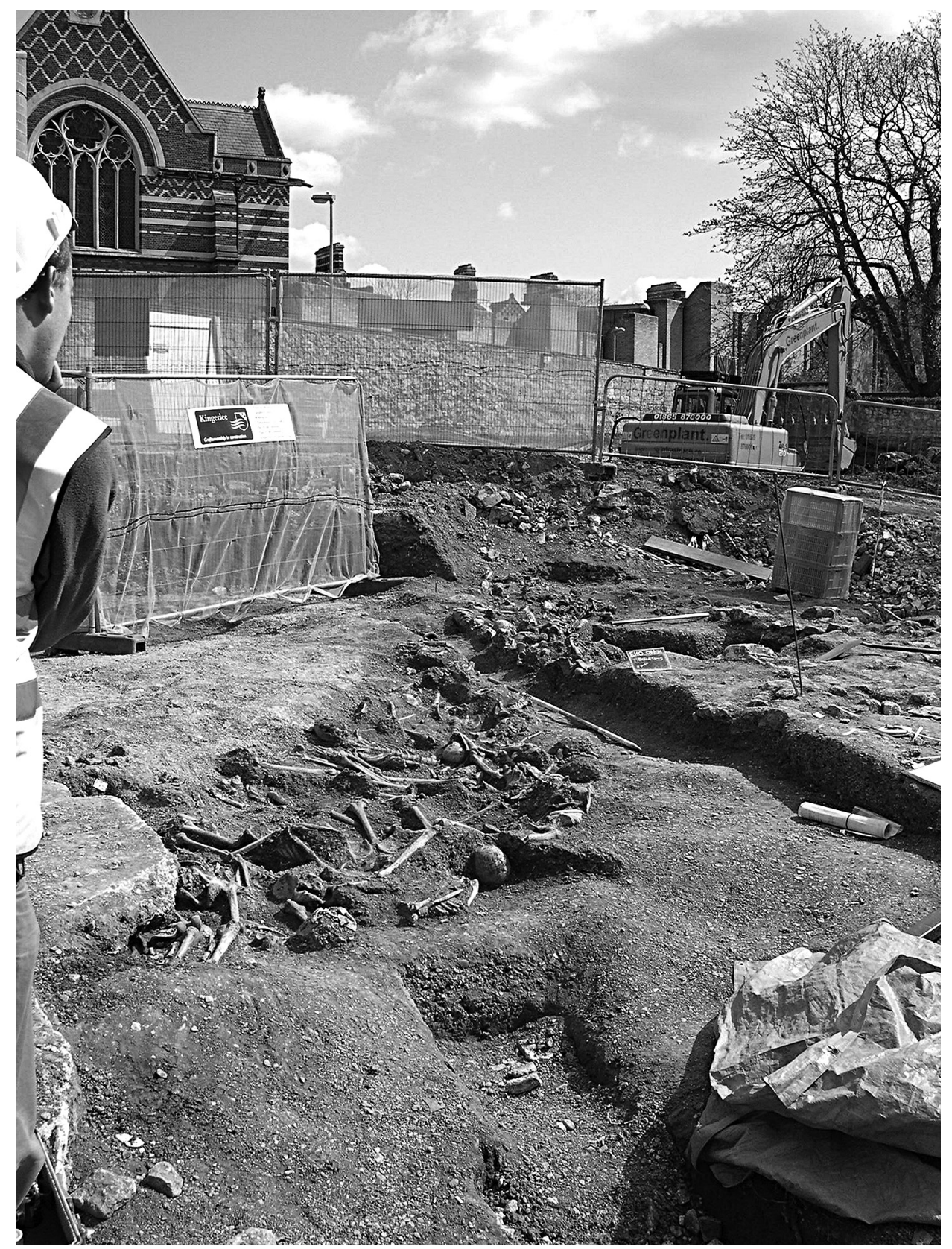

10 Execution burial at St John's College, Oxford. As at Ridgeway Hill, the victims were all male and of apparent Scandinavian origin. It is possible that they, too, died during Æthelred's reign. 


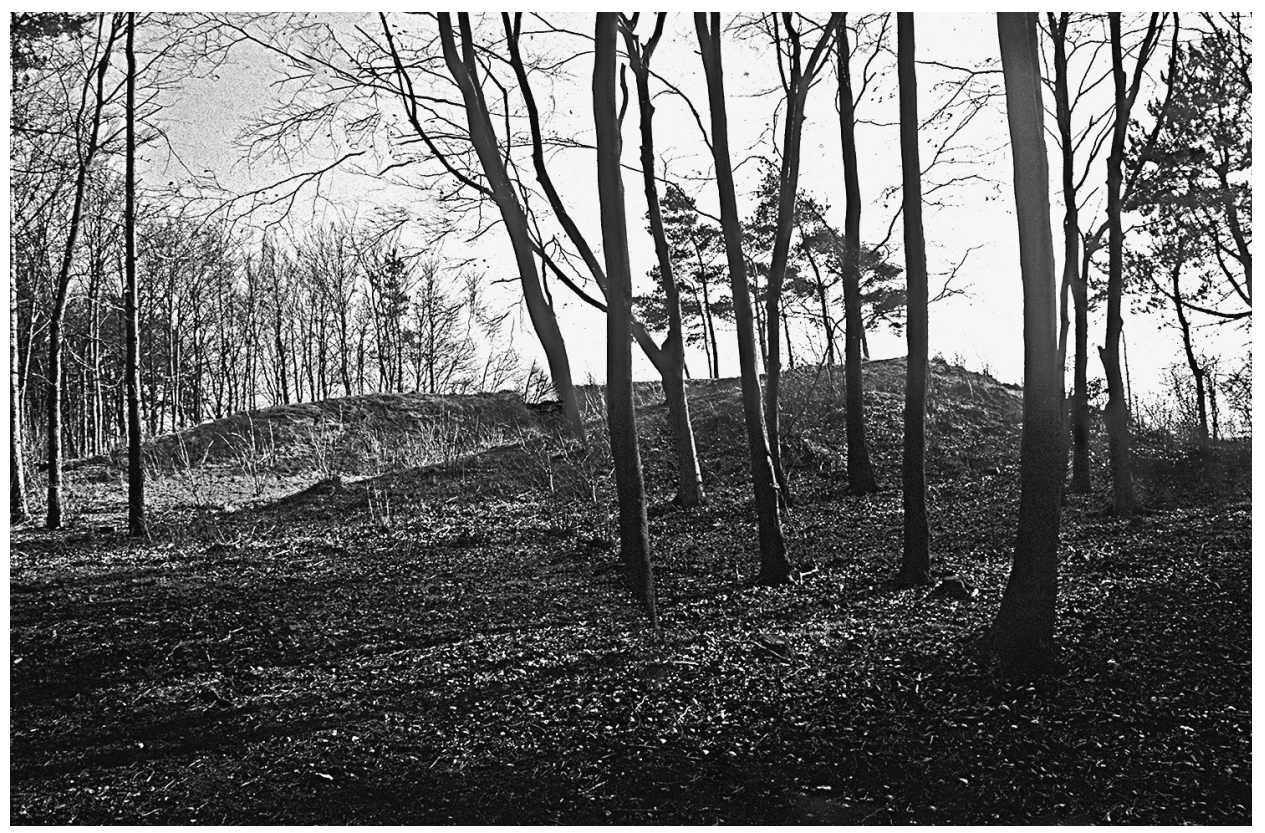

11 Cuckhamsley Barrow (Scutchamer Knob), Berkshire: the local meeting place of the shire, which the viking 'Great Fleet' symbolically occupied in 1006. Legend had it that, if the invaders ever reached this site, they would not make it back to their ships.

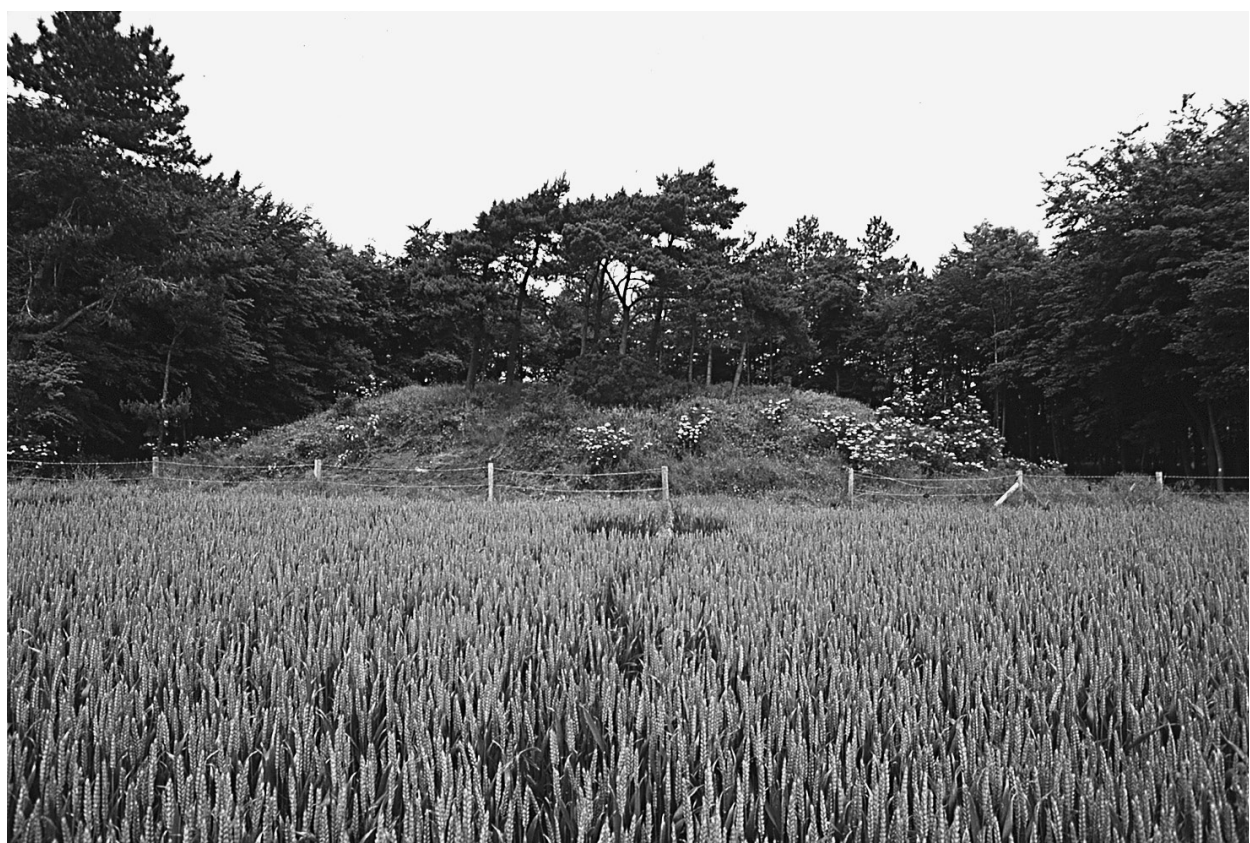


12 The defences at South Cadbury (Somerset): refurbished under Æthelred, probably in connection with the relocation of the local mint from Ilchester.
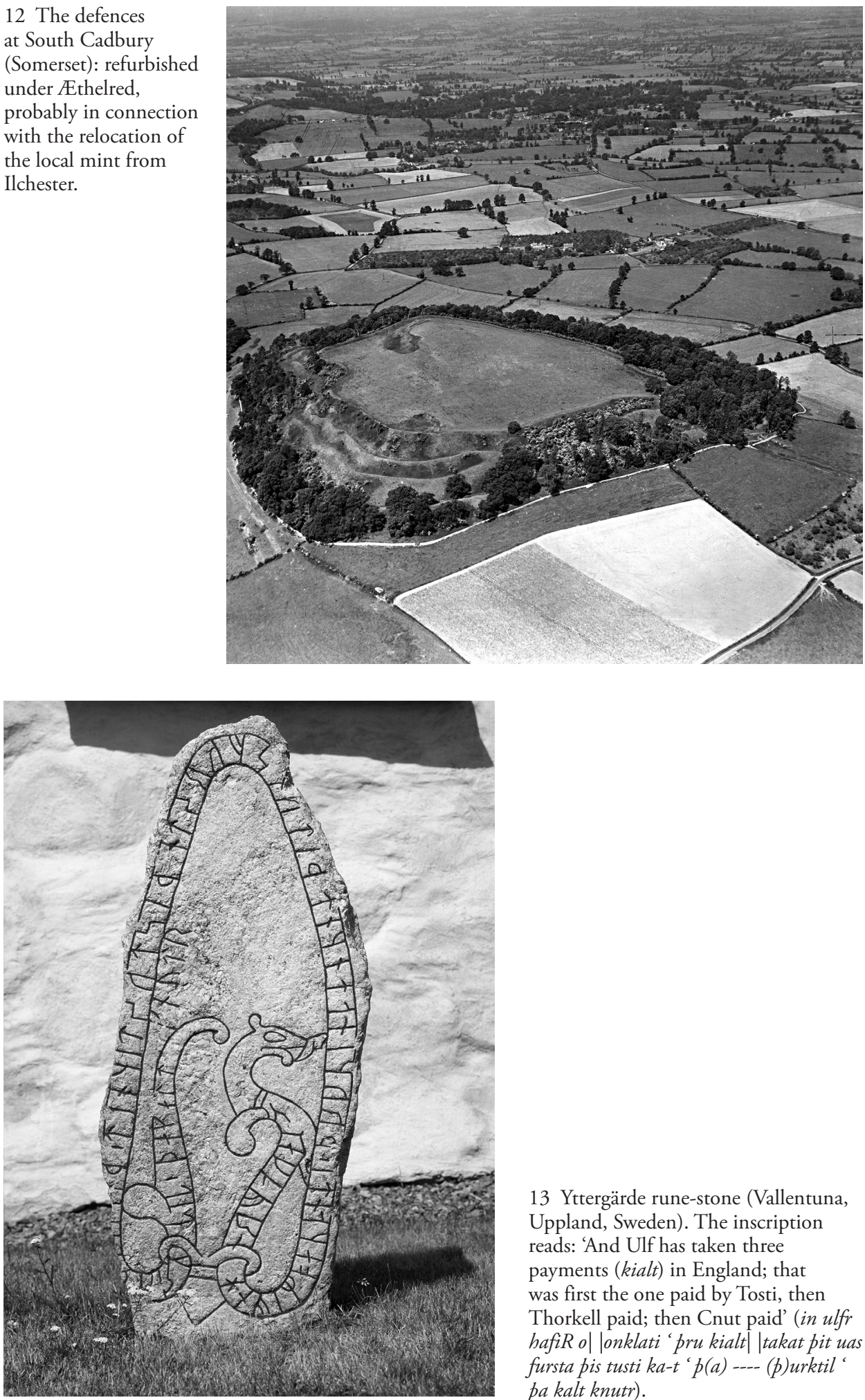

13 Yttergärde rune-stone (Vallentuna, Uppland, Sweden). The inscription reads: 'And Ulf has taken three payments (kialt) in England; that was first the one paid by Tosti, then Thorkell paid; then Cnut paid' (in ulfr hafiR o| |onklati 'pru kialt||takat pit uas fursta pis tusti ka-t ' $p(a)$-..- (p)urktil' pa kalt knutr). 


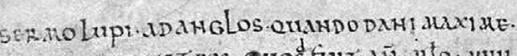

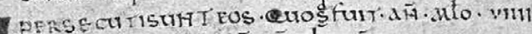

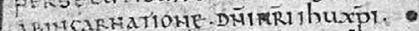

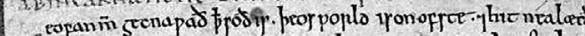

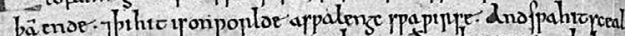
nyde apanze qu reer cocime spetian ypise. purpar on apet-

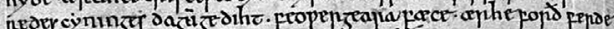

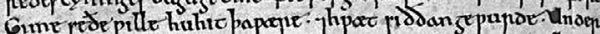

14 Rubrics to the medium version of the Sermo Lupi ad Anglos. These read: 'The sermon of the wolf [i.e. Wulfstan] to the English at the time when the Danes persecuted them most greatly, which was the ninth year of the millennium since the incarnation of our Lord Jesus Christ [i.e. 1009]' (Sermo Lupi ad Anglos quando Dani maxime persecuti sunt eos, quid fuit anno millesimo.VIIII. ab incarnatione domini nostri Iesu Cristi).
15 Rubrics to the long version of the Sermo Lupi ad Anglos. These are identical to those of the medium version, except that VIIII has been replaced with XIIII, making the last phrase read 'the fourteenth year of the millennium [i.e. 1014]'. Note, however, the lighter link of XIIII, which is apparently a later correction.

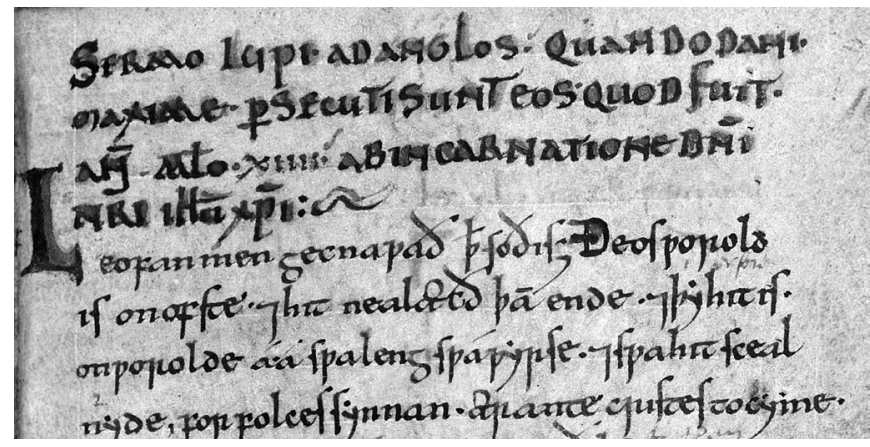

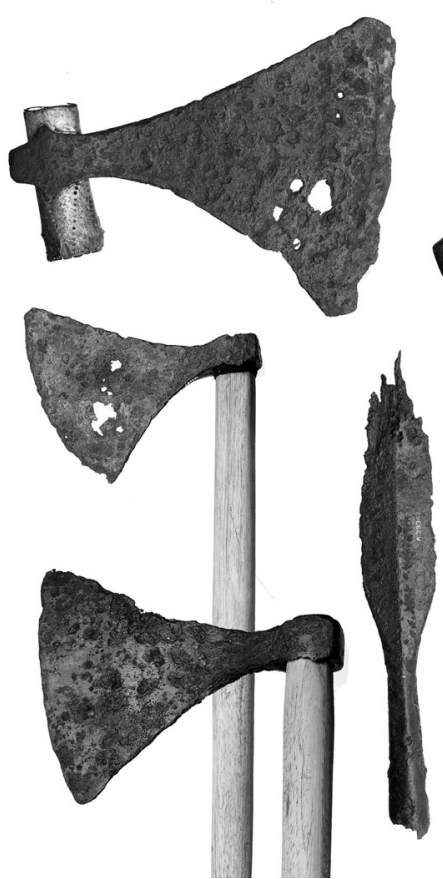
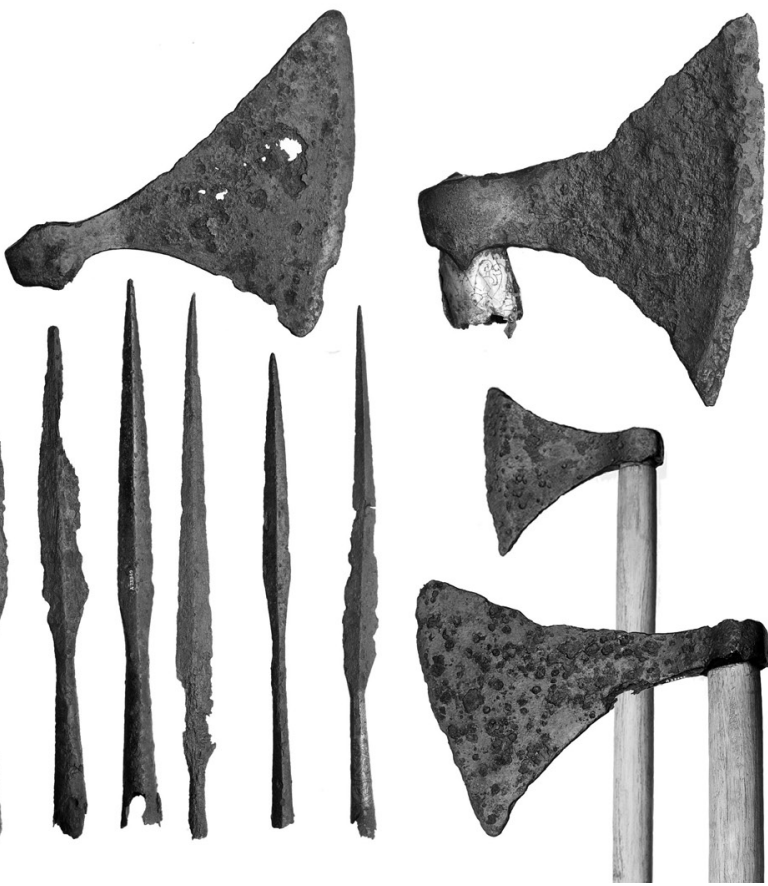

16 An assemblage of weapons found at London Bridge in the 1920s. It was presumably such items that Swein Forkbeard and his men brought in tow when they attacked London in 1013. 